\title{
On the Limits of Digital Storytelling as a Participatory Community-Engaged Methodology
}

\author{
Linnea Beckett \\ University of California, Santa Cruz \\ USA
}

\begin{abstract}
Digital storytelling has been heralded as a powerful and transformative participatory tool for practitioners of community-engaged scholarship. This article draws from an ethnographic case study of Adelante, a university-community collaborative that used digital stories as part of their efforts to enact school and community change. The article explores Adelante's utilization of digital storytelling and explores important ethical considerations related to the dissemination of the stories. The discussion focuses on broader implications for social science researchers interested in digital storytelling and participatory community-engaged methods.
\end{abstract}

Keywords: community-engaged participatory methodologies, digital storytelling, ethics, mediation, representation

\section{Introduction}

In 2006, a group of community leaders from a small agricultural town on the Central Coast of California came together with university professors to envision a new education effort called "Adelante," with the goal of changing the school system to better serve the predominantly Latinx community. Drawing from the philosophies of popular educators such as Paulo Freire $(1970,1990)$ and Myles Horton (1990), community leaders and educational researchers organized dialogues among parents and teachers to investigate the Latinx community's hopes and dreams, with the vision that this process would mobilize collective action toward school and community change. A central strategy to help accomplish this goal was the creation and use of digital stories as a learning tool. As a living anthology of diverse community narratives, Adelante leaders envisioned that this digital archive of student, teacher, parent, and community member stories could facilitate conversations with the greater community and surface the challenges faced by many Latinx students and families, particularly as they interfaced with the school system. 
Digital storytelling has been heralded as a powerful and transformative tool in research and practice (Lambert, 2006). However, as the popularity of digital storytelling increases, so too have the suite of ethical questions. These concerns include the limits of the types of stories that can be told through digital storytelling (Polk, 2010; Poletti, 2011); the influence of the sponsoring organization in shaping the methodology (Thumim, 2009; Dush, 2012); and the dangers of misrepresentation as the digital stories travel from communities in which they were created (Dunford, 2017). This article uses the experiences of Adelante as a case study to illuminate some of the limits of digital storytelling as a participatory community-engaged methodology for social science researchers. The article begins with a brief overview of the process of digital storytelling and its use in social science research, before turning to an in-depth exploration of how Adelante employed this powerful tool. Adelante's political engagement with digital storytelling is discussed along with limits and ethical dilemmas that emerged. Directed toward educational researchers interested in engaging new media methodologies with communities and families, this article seeks to help practitioners of community-engaged scholarship reflect on the narrative limits and representational dangers of digital storytelling as a participatory methodology.

\section{Digital Storytelling and Representation}

In the early 1990s, the Center for Digital Storytelling (CDS) codified a process of digital storytelling as an arts-based method for raising awareness around "marginalized voices" often unheard in media (storycenter.org). Joe Lambert, the founder of CDS, and his colleagues "wanted to motivate people to change their behavior, to change policy, to change the distribution of power and resources...to democratize voice and therefore empower more people than the prior set of analogue tools in contemporary communications" (Polk, 2010, p. 5). Written and narrated by the storyteller, the digital story is a multimodal composition of voice, image, and video to convey a personal experience. Over time the CDS developed curricula, including the popular Digital Storytelling Cookbook, and workshops that outlined a step by step process for implementation.

Research and community initiatives that utilize digital storytelling tend to be "clustered in particular sectors, which include work with young people, within Higher Education, health services, museums or libraries, and initiatives designed to foster citizenship" (Dunford, 2017, p. 315). The humanist philosophy of education and liberation undergirding CDS's approach emphasizes the stories of unheard voices to diversify and democratize the public sphere. Lynch (2017) asserts that the CDS's digital storytelling process is embedded in a Hegelian dialectic and abides by a "theory of reciprocal recognition" (p. 46), which assumes a capacity (and desire) for the oppressor to recognize the inequity and injustice of the storyteller's situation in order for change to occur. Therefore, insofar as this recognition is central to the social force of the digital story, it relies on the viewer humanizing the protagonist. The storyteller takes great risk in aligning with the economies of representation in order to make their story intelligible as well as relatable. From this perspective, "the value of digital storytelling is that it creates an opening for those without identification to produce a consumable identity" (Lynch, 2017, p. 47) within the hegemon. If the digital storyteller wishes to transmit their story through the representations available for viewer recognition and subsequent humanization, then who the viewer is, the context in which the digital story is shown, and how the viewer reads the story become important considerations.

Many social science researchers and increasingly members of the non-profit sector disproportionately document and showcase stories of pain and loss in hopes of garnering material and political resources to ameliorate social and historical inequities (Tuck 2009). The 
researchers and organizers that seek to produce stories of pain, damage, humiliation, and loss rely on a theory of change that assumes marginalized voices need to "testify to damage so that persecutors will be forced to be accountable" (Tuck 2009, p. 414). Using litigation logics and discourse, this "damage-centered" framework requires the storyteller to relive their pain, to be represented through it, and in turn places the power of recognition in the hands of the viewerthe audience - to restore the humanity of the victim. Unfortunately, the storytelling process can generate representations that frame peoples as damaged, broken, and poverty-stricken; these representations, in turn, risk becoming normalized stereotypes and images that speak for entire groups of people. However, this depends in part on who the viewer is and how they read the digital story.

The question becomes how can a digital storytelling process, which relies on the viewer to connect to and humanize the protagonist, generate social change that does not center damage? The digital stories of Adelante faced this challenge. They highlight the longing, the complexity, the hope, and beauty of Latinx farmworker families and im/migrants. However, at the same time, they share stories of pain, humiliation, sadness, and loss. Who reads the story and/or how the story is read leaves room for the hermeneutical possibilities. Negotiating this complex dynamic is an important issue for community-engaged scholars to consider if they seek to employ digital storytelling.

\section{Methodology}

This article draws from data collected from two different studies of Adelante. The first study, conducted from 2010-2012, was exploratory and focused on how Adelante leaders were learning about themselves and their community through creating and using digital stories in their organizing. I interviewed Adelante leaders about the processes of creating the stories and observed sixteen hours of meetings with Adelante leaders where they watched and discussed the digital stories they had produced previously and considered ways in which they could use them as pedagogical tools in community dialogues. The study provided concurrent feedback for Adelante leaders to help them assess their experiences with digital storytelling and determine how they would engage the modality in their future work. The second study, conducted from 2013 to 2015, examined how Adelante leaders theorized their organizational structure and practices and how they used digital stories (and other cultural productions) as reflective devices to make sense of their individual relationships to Adelante and their collective mission as a group. Designed during a pivotal moment in Adelante's history, this second study aimed to represent data from the eight years of Adelante's activities to incite dialogue about strategic possibilities going forward.

These studies positioned Adelante leaders as 'sense makers' and experts in their community and organizing work (Gordon, 1997; Tuck, 2009) and positioned me as a coproducer of knowledge. As a member of Adelante, I was not a leader, but initially supported the group in administrative roles and later in co-facilitative roles as we worked with different groups in the community. At the time I was positioned as a white, Spanish-speaking, middle-class, female, graduate student researcher. I deployed a critically reflexive research design and constantly reflected on these intersectional dynamics as I participated with community leaders and university professors who were often ten to twenty years my elder (Lugones, 2003; Mohanty, 2003).

This article thus draws upon a combination of documentation analysis, field notes, and interviews from Adelante leaders from across the two ethnographic studies. I compiled meeting minutes from the eight years of the collective (2006 -2013) and coded for moments when participants discussed digital storytelling as a modality for their organizing. For this article, I 
draw primarily upon detailed procedural notes and participant-observations during the 2011 digital storytelling workshop. I coded interviews with Adelante leaders from both studies and compiled a description of why Adelante leaders decided to use digital storytelling as a tool for community investigation, of their concerns regarding digital storytelling before they began, of issues that arose as they created the digital stories and discussed their use within Adelante, and of Adelante leaders' reflections on why they chose to tell their story as part of the project's political and pedagogical work.

\section{Adelante's History and Organizing}

Adelante formed in 2006 in an under-resourced and highly segregated school district in a predominantly agricultural town in California. By 2006, public school teachers were working out of contract due to stalled negotiations between the teachers' union and the school district. This was not a new scenario. Teachers, parents, and classified employees had been fighting since the early 1990s for stable working conditions and positive learning environments for students in one of the most under-performing school districts in the state. Fifteen years later, the struggle continued (Bardake, 1994). As the teachers' union advocated for a contract, three community scholars moved through an Ed.D. program, intending to return to their jobs in Adult Education, Migrant Education, and a middle school classroom after developing critical and culturally relevant strategies to support the Latinx community. Study and dialogue on popular education and culturally relevant pedagogies among the Ed.D. students and education faculty soon culminated in a community-university collaboration. A group of community leaders, scholars, and researchers came together in the summer of 2006 to create a long-term consciousness-raising project called Adelante. The collaboration was informed by many years of experience working at the nexus of schools and communities in the region.

Within six months, Adelante began outreach to Latinx parents, many of whom had experienced the frustration with not being heard when advocating for their children at school. For example, Christina was a grandparent and community organizer who had previously participated in school board meetings. She said:

I was disillusioned by the school board meetings. There were very few Hispanics that would raise their hands. Adelante was a way for us to be involved as parents. Being involved in the school board was a good experience,... but I realized there was not much that parents can do. When I would come up with an idea, they would say, 'That is a good idea, Mrs. Lopez, but we can't do anything about it.'

The school board members were interested in having Christina participate in traditional parent involvement activities like fundraising and other auxiliary tasks that would contribute to the normative operations of the district (Baquedano-López, Alexander, \& Hernandez, 2013). When Cristina would suggest calling parents, or trying other outreach methods, she was silenced. She reflected on this when she said, "They want parents to be there, but when you offer ideas, I got the impression that...maybe they don't want all the parents to be there." She continued to attend the school board meetings, but redirected her energies elsewhere. It was at that time she found Adelante. She was interested in Adelante's mission because, as she explained, they intended to "work directly with the parents to make changes in the school."

Adelante drew on the philosophies of popular educators (Freire 1970, 1990; Freire \& Horton, 1990) and the theory and practice of prior organizing and cross-institutional collaborations (see DeShera, 2008; Glass, 2001, 2012; Glass \& Wong, 2009; Harper, 2008; Johns, 2008) and spent the first six months of their time together studying and strategizing. They engaged in collective study of the work of Freire and Horton (1990) and recent school and 
community change efforts (see Oakes, Rogers, \& Lipton, 2006). After which, the group of about fifteen community leaders, Latinx parents, and educational researchers decided on a cultural organizing approach, where they would generate cultural artifacts (letters, plays, etc.) with community members. Their goal was to build capacity across various institutions (e.g., the school, district, teacher's union, adult education, migrant education, community center, social services office) through consciousness-raising dialogue circles.

They began their efforts with parent focus groups to inform the creation of the cultural artifacts. Claudia, a parent leader in Adelante, and José, a Latinx graduate student, conducted these focus groups in Spanish. The focus group leaders asked, "¿Qual son los sueños e metas para sus hijos? ¿Que recursos necesitan para que sus hijos alcancen sus metas/sueños? ¿Que podemos hacer nosotros, las escuelas, para ayudarles a lograr estas metas?" What are your dreams and goals for your children? What resources do you need for your children to achieve these goals/dreams? What can we do, the school, to help the students achieve these goals?

Some of the themes that arose reflected prior research with the Latinx community and schools such as: the importance of education (see Valdés, 1997; Valenzuela, 1999), dignity, respect; the value of family; challenges with mixed status families; stories of migration; language barriers (see Orellana, 2009); safety concerns; and discrimination. Adelante leaders worked with more than 120 parents over the course of three months and gathered rich stories from the everyday lives of Latinx families. The organization now had a clear sense of direction and was ready to think about the best way to utilize these powerful narratives.

\section{The Evolution of Digital Storytelling in Adelante}

As the focus groups concluded, Adelante leaders discussed how they could best share the themes that emerged and present family voices for continued dialogue with community members. Adelante chose to integrate the themes from the focus groups into digital storytelling workshops that would result in the production of three- to four-minute autobiographical vignettes of parents, middle and high school students, teachers, and community members. When designing the workshops, Adelante leaders expressed concern that the vignettes might tokenize residents or harm people. They discussed these concerns and agreed to pilot the digital storytelling process on themselves before extending it to residents, with more peripheral participation in Adelante's organizing efforts. Three digital storytelling workshops occurred between 2007 and 2010 with Adelante leadership. As the leaders experienced the process, they also trained themselves to conduct workshops. In 2011, Luisa, the district's director of parent literacy, worked to link Adelante's digital storytelling process (that had been used in the three prior workshops) with a Latinx parent literacy project at a local elementary school and worked with approximately eight Latinx parents to tell their stories. These Latinx parents did not have prior experience with Adelante.

In mid-October the new workshops began. Following a round of introductions, Luisa started the first meeting by sharing the digital story of Claudia, one of approximately 20 stories compiled from prior Adelante digital storytelling workshops. Luisa selected Claudia's story because it articulated themes that arose when Latinx families were asked about their dreams and goals for their children. Luisa asked the site coordinator to dim the lights as she turned on the projector.

The room goes dark, the wall is filled by an image of Claudia as a child with her family in Mexico, and Claudia's voice fills the room: 
Llegué a los Estados Unidos, asustada de no conocer este país diferente. Me habian dicho: 'El dinero se puede recoger con una carretilla'. Qué ilusión. Todavía llevo el dolor de recoger fresas en los campos, donde pasé ocho años de mi vida. Este era un país extraño, con una cultura diferente. Donde la mujer trabaja más que los hombres. Trabajan: limpian la casa, cuidan a los niños, preparan el almuerzo, se ocupan de la escuela, mi vida fue un caos. Era una barrera estar frente a un maestro estadounidense. Me puso nerviosa y frustrada, pero eso no me detuvo....

I arrived in the United States, scared of not knowing this different country. I had been told, 'Money can be picked up with a wheelbarrow.' What delusion. I still carry the pain of picking strawberries in the fields, where I spent eight years of my life. This was a strange country, with a different culture. Where the woman works more than the men. They work - cleaning the house, caring for children, making lunch, dealing with the school - my life was chaos. It was a barrier to be in front of an American teacher. It made me nervous and frustrated, but that did not stop me....

The digital story continues for another two to three minutes with images of Claudia's life in Mexico, her descriptions of the economic and domestic hardships that fueled her migration to the United States, and what she encountered when she arrived to settle in California. Claudia describes in vivid detail the nervousness and frustration she felt approaching one of her child's teachers. She was worried she would not be understood by the teacher or judged for not having time to change her clothes between fieldwork and picking her child up from school or for speaking broken English with a thick Spanish accent. Claudia's voice then takes a reflexive turn as she recognizes her power and courage to overcome so many challenges, recalling her victories: She went back to school; she learned English, found her voice, advocated for her children, and became a leader in her church and community. As a result of her efforts, Claudia's children and grandchildren are strong, intelligent citizens with opportunities for a healthy and happy future. Her digital story ends on a hopeful note. The images from the story dim and the room remains dark and silent.

Luisa turns on the light and goes to the front to the room. She pauses and then asks, "¿Cómo es similar o como no es a su experiencia? ¿Cómo es similar o como no es a experiencias de personas conocen?" How is this story like or unlike your experience? Like or unlike the experience of others you know? A young Latinx man named Alejandro stands up, visibly emotional. He shares how Claudia's story touched him. Sometimes he also does not have time to go home and change before picking up his daughter from school. He recalls how his daughter is embarrassed to have her dad picking her up, still covered in dirt from his work in the fields, how she has commented on his clothing. Alejandro struggles with the shame he felt in that moment and expresses that it was helpful for him to see that he is not alone in his shame. Similarly moved, other parents echo feelings of fear, shame, hope, and longing, identifying with Claudia's story. A few parents say, "Es mi historia." Claudia's story is my story.

Discussions such as these continued throughout the next few months in weekly, sometimes bimonthly, meetings, focusing on the key elements of the story. The group watched digital stories and analyzed the content as they composed their own stories. Luisa organized this workshop as a partnership between the district parent literacy program and Adelante. The district provided the funding, staffing, technology , and people power through the parent literacy program, and Adelante provided the curriculum and training for the digital storytelling process.

The digital stories were powerful. They often moved viewers into deep conversation about their lives. When Alejandro stood up, he felt a connection to Claudia and was compelled to 
share his story, which catalyzed further dialogue among the parents. To be effective Adelante's digital stories relied on the viewer to recognize the humanity of the protagonist. Adelante's digital storytellers took representational risks when creating their stories. They laid bare their lives, their "damages" (Tuck, 2009), their "worlds" (Lugones, 2003), in the hopes the viewer would connect to the challenges they faced and their hopes for the future. The stories relied on a recognition on the part of the viewer to relate to the protagonist from their varying subject positions. The stories were written from a shared context and were made for Latinx families and K-12 public school teachers for pedagogical purposes.

As the workshops progressed, Luisa introduced the seven elements of a story, modified from the CDS Cookbook, as guidelines for storytelling. The seven elements of a digital story are: (1) point of view, (2) story structure, (3) emotional content, (4) voice, (5) soundtrack, (6) economy, and (7) pacing. For point of view, stories should be told from the first-person perspective. The story should be structured with short, digestible sentences. Storytellers should consider how they can "help audiences care" about their story and talk slowly and clearly for audiences to follow along. Soundtracks can be powerful additions and impact the listener. Storytellers should consider that less is sometimes more with words, images, and video representations of their stories. Lastly, storytellers should pay attention to their pacing of their voice, adding silences and pauses to create a flow as their voice overlays the images and video. Guided by Adelante's digital stories, fellow workshop participant feedback, and the seven elements of a story, the digital storytellers were ushered into telling certain kinds of stories about themselves.

People story themselves every day, formulating life narratives through their social, political, and environmental interactions (Smith \& Watson, 1996; Poletti, 2011). The digital storytelling workshop was another place for people to narrate their lives and part of a "continuum from the intimate to the institutional where individuals [were] asked to produce a life story" (Smith \& Watson, 1996; Poletti, 2011, p. 75). In this sense, the digital storytelling workshops were not necessarily unique in their ability to generate life narratives; however, they did generate certain kinds of life narratives with certain kinds of limits. Poletti (2011) explains that the seven elements of a digital story "coax" a life narrative based on themes of "life, loss, belonging, hope for the future, friendship and love" (p. 81). Narrative strategies that prioritize "narrative accessibility," "closure," and "coherence of theme," limit the possibilities for digital storytelling to question the collective, structural conditions shaping the storyteller's experiences and to be "used as a means of redefining or challenging existing meaning attached to life experience" (Poletti, 2011, p. 75). The stories generated from the discursive and textual processes outlined by CDS align with narrative tropes that are not about redefining or challenging existing meaning in life narrative structure. In contrast, the process prioritizes linking the individual's story to intelligible plot lines and affectively connecting with the audience.

In an effort to avoid framing their stories as damaged-based narratives, the Adelante leaders extended the digital storytelling process of CDS with the implementation of a story circle method to generate their autobiographical stories. Seated in groups of eight to ten people, each participant in a story circle would share a recently drafted autobiographical story. The group would next offer feedback regarding what they found powerful in the story and ask questions to clarify elements that may have been vague (Polk, 2010). As workshop participants watched and discussed Adelante's digital stories, Luisa continued to remind people to think about what stories they wished to tell. Participants easily pivoted from Adelante's stories to their own. The digital stories, like Claudia's, incited responses from parents, almost as if Claudia was in the room and they were in conversation. Parents shared stories of crossing the border, spending a week in the 
desert, navigating everyday life without documentation, family separation, and other powerful stories about loss, death, dreams, and longing.

Adelante's digital storytelling model promoted dialogical exchange. The digital stories touched on everyday oppressions endured by farmworkers and working class im/migrants. The workshop participants responded with their own stories of migration, language barriers (in Mixteco and Spanish), and feeling intimidated to speak to teachers. The prior stories written by Adelante shaped the types of stories that emerged from the parent group. Similarly, the story circles provided an iterative space for the storyteller to refine the story they wished to tell. Through a feedback loop, storytellers would share, the group would respond by emphasizing the powerful elements and would asked the storyteller to expand on these themes. This iterative process of telling stories created a polyphonic environment where the stories being told were from an individual's experience and remembering of that experience, but through the telling the story evolved to include questions, ideas, and perspectives from listeners.

Adelante leaders understood limits of the methodology to create narratives that questioned structural conditions and embedded the digital stories in a problem-posing, questiondriven curriculum of community investigation, which is visible in Luisa's questions. As such, Adelante designed the pedagogical engagement as the site of critical analysis. They organized the curriculum to support a collective analysis of the digital stories, where viewers would interact with the representation of everyday life, link the personal to the political, and collectively imagine alternative life narratives. In framing the pedagogical engagement as the site of critical analysis and not the stand-alone digital stories, Adelante leaders committed to embedding the digital stories in the geographic, pedagogical, and political context of Adelante to limit to whom and how the digital stories would be viewed. Otherwise, the stories always already ran the risk of being read as "damage-centered" (Tuck, 2009) and reproducing stereotypes of Latinx im/migrants.

\section{Telling Stories for Each Other}

The stories recorded in Adelante's workshops were not written to be read/viewed outside of the pedagogical or community context of Adelante. Adelante leaders envisioned a space where Adelante facilitators and groups of K-12 teachers or Latinx parents would have time to discuss the stories and enter into a community analysis of historical and social inequities. Among all storytellers, motivations varied for sharing their stories, however all Latinx parents interviewed explained that they shared their stories with the expressed desire to communicate with other Latinx families in the region.

Claudia and Gabriela, two Latinx parents in the 2010 workshop, shared their reasons for telling their stories. Claudia joined Adelante as a parent leader within six months of its formation in 2006. She grew up in Mexico and migrated as a girl, leaving her family behind. Now a grandmother, she works at a local food bank. Her story highlighted experiences as an immigrant mother in California and advocating for her children's education. When asked why she told her story, Claudia shared that she believes some people have given up hope and maybe through witnessing her experience of relocation she could give viewers "a little power" to recognize that "they are not alone." Claudia saw the feeling of isolation as a structural effect of migration and recognized a need for people to share their experiences to know they are not alone. She explained:

People are having the same problems.... Sometimes we don't have an opportunity to talk with a lot of people. Yeah, to tell them, 'I want the same with you, don't be sad, you can do it. You can go to the schools and you can find a way to talk to the teachers.' 
Claudia understood im/migrant parents share similar challenges. There are few opportunities for parents to have conversations about these difficult topics, to connect and find ways to support each other. Claudia believed that if she told her story and shared it with other Latinx im/migrants, that her story could open up dialogical space for parents to talk about their feelings, promote a sense of solidarity, and find ways to "talk to the teachers" and advocate for their children.

Gabriela became part of Adelante through her relationship with Claudia. She started frequenting the Adelante meetings within a year of Adelante's formation, and over time, Gabriela assumed a leadership role. She told her story in 2010 with three other Latinx parents. Gabriela was asked to share her story years prior and her initial response was "no." She was scared to talk about her life. However, after she saw the digital storytelling process and became familiar with the work of Adelante, Gabriela overcame her fear and decided to share her story. She saw that her story was different from the ones previously told and began to believe it was important to share her perspective and experiences. She states:

Ya habia visto la historia de Claudia, dijimos que mi historia, no no es igual y yo creo que es importante de contar una historia como la mia porque se van a identificar muchas personas que están igual como yo...muchas personas van a sentirse identificadas con esta historia. Que se van a dar cuenta que no son las únicas. Entonces se desenvuelven, la sacan y otros padres pueden o podemos hacer algo con mi historia pues de ayudar a mas personas.

I saw Claudia's story and my story is not the same. I think it is important to tell a story like mine because many people will identify with my story because they are the same as me.... many people will identify with this story. They are going to realize that they are not the only ones. Then they develop, they create [the story] and other parents can or can do something with my story as to help more people.

She saw her audience as other parents who had similar life experiences as hers, specifically undocumented mothers and fathers. She was confident that when parents saw her story that they would easily relate to the experiences she described and recognize that they were not alone; that other people struggle with similar issues of isolation, exploited labor, unfamiliar language, substandard housing, and challenges advocating for their children at school. She hoped her story would

dejar [los padres] de ser tan tímido, de que hablen, de que no importa si no tenemos papeles o porque mas que nada de hablar en las escuelas de que no se quedan callados en lo que es injusto porque muchas personas se quedan calladas y ya no hablan ni con la directora, ni con nadie ya.

let the parents not be so shy, for us to speak, and not care if we have documentation or not, more than anything to speak in the schools and not stay quiet in what is unjust because many people stay quiet and do not speak, not even the principal, not with anyone, anymore.

Gabriela hoped her story would inspire people to speak and to reveal the injustices that she sees between the parents and the schools. In telling her story as an undocumented parent, she envisioned that her sharing would incite other undocumented parents to step forward and begin to advocate for their children. Similar to Claudia, Gabriela saw her story as a potential site to 
promote dialogue among parents, specifically undocumented parents to speak about issues that may inhibit their participation in their child's schooling. When Adelante leaders shared Claudia and Gabriela's stories with Latinx families, deep and rich dialogue often ensued. Their stories remind people that they were not alone, generating connection and community, all of which were important components of Adelante's organizing work.

Claudia and Gabriela describe their audience as Latinx parents in their community; other mothers and fathers who have shared experiences with im/migration, housing, language, and parenting children through the K-12 public school system. Claudia and Gabriela are just two of many Latinx parents who chose to write their own autobiographical digital stories. These stories often merge hope and fear, longing and love, and pain and desire, for an audience of peers, neighbors, and co-workers.

\section{On the Limits in Story Dissemination}

Many of Adelante's leaders have shared concerns about digital storytelling tokenizing or pathologizing community voices. The stories, once finished, are cultural artifacts that abstract life as the story moves from embodied experience to a digitized object. The digital short story commodifies the experiences and knowledge of the storyteller, showing a partial view of a complex life. Although Adelante chose to create and use digital stories, their concerns generated anxiety among Adelante leaders. They often discussed how to best use the digital stories and addressed these anxieties on a case-by-case level.

In contrast to the CDS dissemination strategy, which consists of posting the stories on an open-access website, Adelante leaders did not intend for the stories to be disseminated widely. The digital stories of Adelante were intended to be read/viewed together, in and with the community and Adelante. The stories were meant for Adelante's own community work. As Claudia and Gabriela stated earlier, the stories they wrote were for other Latinx parents, not for general audiences. Some teacher leaders in Adelante directed their stories toward other teachers and the school district, framing the scope of their audience more broadly than just Latinx parents. These were strategic decisions among Adelante leadership and reflected to whom Adelante considered themselves accountable.

Adelante leaders dealt with decisions about sharing the stories with particular audiences on a case-by-case basis, always asking permission to share a story from the storyteller and providing an explanation of the audience and context in which the story would be shared. This allowed storytellers to refuse the showing of their story for any reason and without explanation at any time. For example, Christina wrote her story in 2008. Shortly thereafter, she had to leave Adelante to care for her aging father. Upon her return, she asked that Adelante no longer use her story. She continued as an activist and organizer in the community and asked, for the sake of her family's privacy, that her story not be shown. Adelante quickly responded by making sure her story was no longer viewed. Adelante leaders always defer to the desires of the individual storyteller. Adelante was clear that the digital stories were not meant to travel outside of Adelante, and even their curation within Adelante produced different community audiences to view the story. The ethical commitment of how to use the digital stories and with whom to share these stories resides in how Adelante leaders chose to use (and sometimes not use) the digital stories as pedagogical tools, and power does not reside in the university's hands.

\section{Considerations for Social Science Researchers}

Adelante's commitment to their community and their intentions for the use of their digital stories highlight the ethical complexities in the creation and use of digital stories as part of a political and pedagogical project. I propose the theoretical framing outlined thus far can guide 
social science researchers toward more ethical engagements with digital storytelling in their participatory community-engaged methodologies. Here, I offer considerations for social science researchers intent on using digital storytelling.

\section{Digital Stories Are Produced in Context}

Digital stories are products of a mediated storytelling process that includes the storyteller, the facilitator, the participants in the workshop, and the funding agency. According to Dush (2012), digital storytelling "can support a range of ideologies and subject positions," and digital storytelling should be understood as a mediated process of narrative production among the "commissioning agency, the storyteller, the facilitator-practitioner and the audience" (Dunford, 2017 , p. 315). With varying levels of power, the agency, facilitator-practitioner, and the storyteller shape the expression and scope of that expression. The storytelling process is culturally and politically mediated (Dush, 2012; Dundford, 2017; Thumim, 2009) and "the product of a discursive arrangement with their producing institution" (McWilliams, 2009, p. 115). Therefore, sponsoring institutions mediate the digital storytelling process that often, in turn, support the institution (Dush, 2012). Sponsoring institutions include schools, non-profits, service providers and individuals who are employed by any of these and other institutions.

In Adelante, the digital stories proved to be composites of an iterative and polyphonic process that integrated voices from focus groups, workshop participants, and Adelante facilitators. The process was bound by the capacities and political vision of Adelante. Adelante's workshops opened space to coax stories related to the themes previously identified in Adelante efforts; it also foreclosed possibilities for other stories to be told. For example Luis, one of the Latinx parents, arrived at the digital storytelling workshop with a story about his experiences with domestic violence as a young man in Mexico. While telling his story, he was guided to explore other themes in his life and not focus on domestic violence, but on experiences as a parent and interacting with the US school system. Adelante leaders and facilitators recognized domestic issues as valid and important to the overall discussion; however, Adelante leadership decided that they did not have the capacity to take up domestic violence in dialogue as part of the project's praxis without the proper psychological support available. As such, his initial story did not fit within the dominant themes codified among Adelante leadership for future pedagogical purposes and Adelante leaders asked him to share another story.

Luis' process illustrates the way the digital storytelling process molded his story. Social science researchers seeking to engage digital storytelling in their methodologies must include an analysis of the contexts, people, institutions, and pedagogies of digital storytelling that produce the stories. The digital story cannot be fully understood as a representation of an individual. The story is a composite formed through a mediated process among various stakeholders. The negotiations that occur through the digital storytelling process may signal epistemic violence or otherwise invisible power differentials. The interactive process among stakeholders can help the researcher understand the levels of agency and power various individuals have in shaping the digital story.

\section{Examine the Digital Storytelling Process}

At the start of this article, I explained how CDS's humanist philosophy shapes the digital storytelling curriculum and consequently limits the types of stories told. The digital stories that follow the CDS philosophical tenets and methodology in education, health and, increasingly, in public discourses on citizenship, rarely disrupt normative tropes or representations. In fact, the digital story relies on these tropes to be legible to the general public. Therefore, it is a stretch to 
suggest (as CDS does) that the digital stories, as stand-alone representations, bring about changes in policy and redistributions of power and resources.

This article explored the theoretical tenets of the CDS digital storytelling process to reveal a "theory of reciprocal recognition" (Lynch, 2017). The digital story relies on the viewer to recognize and humanize the protagonist, which then can lead to transformation. This investigation of the digital storytelling process throws into question the promises of CDS and allows for a re-theorizing of digital storytelling in various and potentially divergent ways. I urge social science researchers to trace the theories of change not only proposed by the digital storytelling agency or individual, but the actual process itself.

\section{Locate the Site(s) of Critical Analysis}

Adelante understood that the digital story's power to affect change relies on how the stories are engaged in the public sphere. This includes the manner in which Adelante decided how community members would watch the stories and discuss the stories to generate potentially disruptive understandings of the normative tropes they represented. Adelante developed their digital storytelling project with keen attention to the ethical issues of the politics of representation and narrative. They chose to "coax" life narratives outlined by the themes that arose from everyday lived experiences of Latinx families, teachers, and students with the intention to present these stories to generate dialogue toward social change.

While Adelante's organizing work was based in cultural organizing and had a similar humanist foundation as CDS, Adelante's political and pedagogical agenda differed. CDS's workshops are not situated in larger commitments to communities in which the stories are told. In contrast, Adelante's coaxing was set by the themes and dialogues among community members and part of a praxis, a pedagogical-public learning process (conversation with Glass, 2018). Adelante leaders wrote their stories to reflect the themes generated in focus groups with Latinx families where they discussed participants' hopes and dreams. They chose digital storytelling as the method to share stories, generate dialogue, and raise consciousness around everyday lived experiences. Adelante hoped these discussions would generate collective actions for social change, to make possible "another school and another community" (Adelante's slogan).

Adelante framed the digital stories as representations of everyday life to accompany a problem-posing, question-driven curriculum that would, in turn, examine the structural causes that produced the stories. The pedagogical engagement was the cite of critical analysis. Adelante understood that the digital stories would not disrupt the status quo, but the dialogue,- - the ways in which community members engaged and analyzed the digital stories - could support critical consciousness raising (Freire, 1970). The digital stories emotionally moved viewers and generated deep dialogue. More can and should be learned about how viewers moved into critical analysis of the digital stories, while recognizing that these sites of study are ethically fraught, challenging to explore, and, in some cases, may not be spaces where social science researchers can or should collect data.

\section{Frame the Limits of Dissemination}

Adelante's stories were not written to challenge existing life narratives or to unpack the structure that produced these life contexts. The storytelling process deployed by Adelante coaxed legible life narratives that privileged intelligibility, closure, and coherence with Adelante's themes. Prioritizing legibility, closure, and identification limited the types of stories that could be told to the economies of representation defined by the hegemon (Lynch, 2017). The coaxed life narrative did not disrupt normative tropes and as such, the digital story can reify hegemonic representations through rewriting the same history that many people are already aware exists. For 
example, the reaffirmation of the tropes that script the life of the Latinx im/migrant leaves the possibility for viewers to overlook resistance in the story and respond with "arrogant perception," pity, or ambivalence (Lugones, 2003).

The stories were not meant to further pathologize or stereotypes Latinx families or K-12 teachers. Yet the question remains, how can a digital storytelling process, which relies on the viewer to connect to and humanize the protagonist, generate social change that does not center damage? Adelante answered this question, in part, by uplifting why and to whom the stories were told. The potential for damage-centering proved to be pedagogical and contextual. When the digital stories were decontextualized (shown to unintended audiences) the possibility for a damage-centered pedagogy to override Adelante's curriculum was heightened. Social science researchers, as part of the settler colonial academy, often seek out and participate in damagecentered research. We abide by the theory of change "used to leverage reparations or resources for marginalized communities yet simultaneously reinforces and reinscribes a one-dimensional notion of these people as depleted, ruined, and hopeless" (Tuck, 2009, p. 409). Guided by these logics, researchers and other viewers may seek to find the damage in the stories, even if the stories also highlight wisdom, hope, and power. Adelante's work illuminates the pedagogical quality of damage-centering as part of a larger settler colonial and white supremacist project.

Discussions of curation and dissemination of stories in Adelante reflect important ethics of representation for social science researchers' intent in community-engaged participatory methodologies. Social science researchers should pause and contend with the complexities of the ethical and political issues underlying the power dynamics of representation, narrative, and various forms of testimony. Community partners should be central in decisions regarding the use of story in social science research. Researchers, when choosing to engage in this work, should be open to not telling the stories they might otherwise seek to tell. Social sciences researchers should frame the limits of dissemination of digital stories through a lasting commitment to the storytellers, which includes honoring their desired audiences, even if this means refusing to show or tell stories to the researcher's desired audience.

With critically designed participatory projects such as Adelante, there are a variety of ways in which people opted out of sharing, refused to share, were never asked to share, or only share one thread of a vast tapestry of life stories. In addition to why and how stories were told, the stories never told, the negotiations that occurred before the story was complete, and individuals' perspectives on why they shared their stories are also important and productive sites of reflection for social science researchers. The silences and absences are important data. Not because the social science researcher should seek ways in which these stories should be told, but for the research/er to recognize and "limit the conquest and colonization of knowledges" (Tuck \& Yang, 2014, p. 225) and respect the bounds of what knowledge should be shared. Adelante framed their ethical commitment to the stories through their deep pedagogical engagement with the stories and their clarity on the themes they knew they could take up in their praxis. Digital storytelling is a potentially powerful tool, but one that must by carefully utilized to honor and respect those who are willing to share their stories.

Acknowledgements: Thank you to all the Adelante leaders for your work, dedication and guidance through this study. Special thanks to Professor Ronald Glass and Dr. Flora Lu for your feedback 


\section{References}

Baquedano-López, P., Alexander, R. A. \& Hernandez, S. J. (2013). Equity issues in parental and community involvement in schools: What teacher educators need to know. Review of Research in Education, 37, 149-182.

Bardacke, F. (1994). Good liberals, Great Blue Herons: Land, labor and politics of Pajaro Valley. Santa Cruz, CA: The Center for Political Ecology.

DeShera, G. E. (2008). Community Collaboration in School Improvement. (Doctoral dissertation). Retrieved from ProQuest Dissertations \& Theses Global. (AA13318548)

Dunford, M. (2017). Understanding voice, distribution and listening in digital storytelling. Participations: Journal of Audience \& Reception Studies, 14(1), 313-328.

Dush, L. (2012). The ethical complexities of sponsored digital storytelling. International Journal of Cultural Studies, 16, 627-640.

Freire, P. (1970). Pedagogy of the oppressed. New York, NY: Continuum.

Freire, P. (1990). Pedagogy of freedom: Ethics, democracy, and civic courage. Lanham, MD: Rowman \& Littlefield Publishers.

Glass, R. D. (2001). On Paulo Freire's Philosophy of Praxis and the Foundations of Liberation Education. Educational Researcher, 30, 15-25.

Glass, R. D. (2012). Cultivating compassion: Lessons learned from community and family. In L. G. Denti \& P. A. Whang (Eds), Rattling Chains: Exploring Social Justice in Education (pp. 67-72). Rotterdam, Netherlands: SensePublishers.

Glass, R. G. \& Wong, P. L. (2009). Prioritizing urban children, teachers, and schools through professional development schools. Albany, New York: SUNY Press.

Gordon, A. (1997). Ghostly matters: Haunting and the sociological imagination. Minneapolis, MN: University of Minnesota Press.

Harper, H. R. (2008). Hearing the voices of Mexican immigrant parents: Participatory action research building a space to explore and report on how parents experience their children's schools in California. (Doctoral dissertation). Retrieved from ProQuest Dissertations \& Theses Global. (3318549).

Horton, M. \& Freire, P. (1990). We make the road by walking: Conversations on education and social change. Philadelphia, PA: Temple University Press

Johns, J. R. (2008). Abriendo caminos: Peer coaching of culturally relevant pedagogy for teachers of adolescent emergent bilinguals. (Doctoral dissertation). Retrieved from ProQuest Dissertations \& Theses Global. (3318550).

Lambert, J. (2006). Digital storytelling: Capturing lives, creating community (2nd ed). Berkeley, CA: Digital Diner Press.

Lugones, M. (2003). Pilgrimages/Perigrinajes: Theorizing coalition against multiple oppressions. Oxford, England: Rowman \& Little Field Publishers, Inc.

Lynch, H. (2017). Troubling the humanist teleology of digital storytelling. Visual Methodologies, $5(1), 45-50$. 
On the Limits of Digital Storytelling as a Participatory Community-Engaged Methodology

McWilliams, K. (2009). Digital storytelling as a 'discursively ordered domain.' In K. Lundy (Ed.), Digital storytelling, mediatized stories: Self-representations in new media (pp. 147160). New York, NY: Peter Lang.

Mohanty, C. T. (2003). Feminism without borders: Decolonizing theory, practicing solidarity. Durham, NC: Duke University Press.

Oakes, J., Rogers, J. \& Lipton, M. (2006). Learning power: Organizing for education and justice. New York, NY: Teachers College Press.

Orellana, M. F. (2009). Translating childhoods: Immigrant youth, language, and culture. Piscataway, NJ: Rutgers University Press.

Poletti, A. (2011). Coaxing an intimate life: Life narrative in digital storytelling. Continuum: Journal of Cultural and Media Studies, 25, 73-83.

Polk, E. (2010). Folk media meets digital technology for sustainable social change: A case study of the Center for Digital Storytelling. Global Media Journal, 10(17), 73-83.

Smith, S. \& Watson, J. (1996). Introduction. In S. Smith \& J. Watson (Eds.), Getting a life: Everyday uses of autobiography (pp. 1-26). Minneapolis, MN: University of Minnesota Press.

Thumim, N. (2009). 'Everyone has a story to tell': Mediation and self-representation in two UK institutions. International Journal of Cultural Studies, 12, 617-638.

Tuck, E. (2009) Suspending damage: A letter to communities. Harvard Educational Review, 79, 409-428.

Tuck, E. \& Yang, K. W. (2014). R-Words: Refusing research. In D. Paris \& M. T. Winn (Eds.), Humanizing research: Decolonizing qualitative inquiry with youth and communities (pp. 223-247). Thousand Oakes, CA: Sage Publications.

Valdés, G. (1996). Con respeto: Bridging the distances between culturally diverse families and school: An ethnographic portrait. New York, NY: Teachers College Press.

Valenzuela, A. (1999). Subtractive schooling: U.S.-Mexican youth and the politics of caring. Albany, NY: State University of New York Press. 